\title{
Impact of Zika virus for infertility specialists: current literature, guidelines, and resources
}

\author{
Jamie P. Dubaut ${ }^{1}$ - Nelson I. Agudelo Higuita ${ }^{2}$ - Alexander M. Quaas ${ }^{1}$
}

Received: 29 April 2017 / Accepted: 16 June 2017 /Published online: 7 July 2017

(C) Springer Science+Business Media, LLC 2017

\begin{abstract}
In the past 2 years, Zika virus has emerged from obscurity onto the world stage - traversing and transcending clinical specialties, basic science disciplines, and public health efforts. The spread of Zika virus has serious implications for the specialty of reproductive endocrinology and infertility. Our patients, practices, and labs - worldwide and specifically in the USA - have been impacted by this teratogenic, sexually transmitted, largely asymptomatic virus. While the World Health Organization's Public Emergency of International Concern designation has lapsed as major epidemics have subsided and understanding of risks is in part clarified, the acute and long-term threat to pregnant patients is not over. The risk of wider spread in the USA is not insignificant, the subtler and long-ranging consequences beyond microcephaly are not fully known, large geographic areas of risk still contain naïve populations, and whether Zika will continue to be an intermittent risk in endemic areas is uncertain. Staying up to date with the burgeoning research on Zika virus is an important objective for the infertility specialist. Here, we review in detail the most relevant recent developments, discuss applicable guidelines, and propose strategies for contributing to a reduction in the risk and burden of Zika virus.
\end{abstract}

Jamie P. Dubaut

Jamie-Dubaut@ouhsc.edu

1 Section of Reproductive Endocrinology and Infertility, Department of Obstetrics and Gynecology, University of Oklahoma Health Sciences Center, P.O. Box 26901, COMB 2400, Oklahoma City, OK 73126-0901, USA

2 Section of Infectious Disease, Department of Internal Medicine, University of Oklahoma Health Sciences Center, Oklahoma City, OK 73014, USA
Keywords Zika $\cdot$ Sexual transmission $\cdot$ Reproduction Infertility

\section{Background}

On 1 February 2016, the World Health Organization (WHO) announced that the Zika virus (ZIKV) epidemic and its association with Guillan-Barré syndrome (GBS) and microcephaly constituted a Public Health Emergency of International Concern (PHEIC) [1]. The WHO removed ZIKV from PHEIC status as of November 2016 [2], while stating that the ZIKV threat requires a long-term coordinated response. The seminal review by Musso and Gubler details the emergence of ZIKV from obscurity in Uganda in 1947, the first outbreak in Yap Island in 2007, a larger outbreak with the first GBS and microcephaly cases in French Polynesia in 2013, its introduction to Brazil beginning 2014, to PHEIC in 2016 [3].

\section{Zika virus symptoms}

In a sample of 557 of Yap Island's 7400 residents, $73 \%$ showed evidence of infection with ZIKV by IgM antibodies. Thirtyeight percent of ZIKV IgM-positive residents had clinical symptoms such as fever, rash, conjunctivitis, and arthralgia, compared with $19 \%$ of ZIKV IgM-negative residents, indicating that an estimated 19\% of ZIKV symptoms could be attributed to ZIKV [4]. This led to the dogma that $80 \%$ of ZIKV infections are asymptomatic. This estimate of symptomatic infections may be low based on more recent studies with conflicting results. In a study of asymptomatic blood donors who screened positive for ZIKV in French Martinique, 55\% became symptomatic by telephone follow-up 7 days later [5]. In a study on French Polynesian residents with serologic evidence of ZIKV infection, 57\% (2013-2014, $n=196)$ and 47\% (2015, 
$n=700)$ of the general population, and $71 \%(n=476)$ of schoolchildren reported prior clinical symptoms; however, symptoms in people with negative serology were not quantified [6].

Best estimates of the ZIKV incubation period before symptoms are 3.5 to 10 days, then symptoms may last a few days to a week [3]. In an effort to standardize the classification and reporting of ZIKV cases, the WHO published case definitions for ZIKV disease: clinical criteria are met if fever or rash is present in addition to either arthralgia, arthritis, or conjunctivitis [7]. The Centers for Disease Control and Prevention (CDC) case definition of ZIKV infection differs in that any patient having at least one symptom meets clinical criteria for algorithm and guidance purposes. However, local and state health jurisdiction guidelines may have additional requirements to qualify for testing based on symptoms [8]. In Oklahoma, for example, two of four symptoms (fever, rash, conjunctivitis, arthralgia) are required to meet clinical criteria for ZIKV screening purposes [9].

\section{Zika virus transmission}

ZIKV is a flavivirus (molecular taxonomy classification) and an arthropod-borne virus (acronym: arbovirus) that is transmitted by the Aedes aegypti and Aedes albopictus species of mosquito [3]. Unlike other arboviruses, non-bloodborne transmission of ZIKV including sexual transmission is possible and increasingly reported in the literature: a prior systematic review summarized 10 reports regarding the presence of ZIKV in genital fluids and specific modes of sexual transmission [10], an updated systematic review on the topic included 33 of such reports [11].

Symptomatic male-to-female vaginal sexual transmission is the most frequently published mode of sexual transmission. The first case occurred in 2008, and this case reported that sexual transmission may have occurred just before symptom onset in the male [12]. Sexual transmission occurring as long as 34-41 days after the onset of symptoms in the partner has been reported [13]. Oral sex transmission, male-to-male transmission, and female-to-male transmission have been documented, primarily in isolated case reports [11]. No femaleto-female transmission has been reported. The first asymptomatic male-to-female transmission was detected in France due to screening guidelines for the couple utilizing assisted reproductive technologies (ART) [14]; at least two additional asymptomatic sexual transmission cases have been reported [11].

ZIKV RNA has been detected in semen by reverse transcriptase-polymerase chain reaction (RT-PCR) from days 3 to 188 after symptom onset, and the longest ZIKV which has been cultured from semen is 69 days [15-17]. The largest cohort of ZIKV-confirmed symptomatic males with semen samples in the literature comes from Puerto Rico [18].
Models based on these 55 semen samples suggest that the 95th percentile of time until loss of ZIKV positivity by RTPCR for semen is 81 days (95\% CI, 64 to 98). However, that study and other case series have detected ZIKV in semen by RT-PCR in only $50 \%$ of males positive for ZIKV infection by serum tests [19]. When similar modeling was applied only to those who initially tested positive for ZIKV in the semen $(n=33)$, the 95 th percentile of time until loss of ZIKV positivity was 99.9 days (95\% CI, 75.4 to 124.6 ) [18].

Of concern, one negative semen RT-PCR test does not guarantee loss of positivity: the second longest report (185 days) of ZIKV by RT-PCR in semen [20] as well as a report of ZIKV in a vasectomized male with confirmed azoospermia [21] showed that semen tested negative in between two positive tests.

The review by Moreira et al. included seven women with ZIKV detected by RT-PCR up to day 13 after symptoms in female genital secretions, including endocervical swabs, cervical mucus, and vaginal samples [11]. While ZIKV RNA was detectable, ZIKV could not be cultured from female genital secretions [22]. The largest study of ZIKV testing in female genital secretions to date found that 28 of 59 pregnant women at risk of ZIKV infection during the outbreak in Ecuador had positive ZIKV detected in Pap smear specimens. Twenty-five of these women also had ZIKV-positive serum [23].

Probable transmission by blood products is under investigation in Brazil [24], and blood in the continental USA has screened positive in donors from states with local mosquito transmission [25] as well as states without local transmission [26]. Needlestick transmission in a research lab as well as close personal contact transmission between a highly viremic patient and his family member have also been documented in the USA [27]. One report has found ZIKV virus by culture in breast milk [28]. However, artificially ZIKV-spiked breast milk loses its infectivity when simply stored for 3 days or when pasteurized [29].

\section{Congenital Zika Syndrome}

Based on the accumulation of evidence - including that which fueled the PHEIC - and using Shepard's criteria for teratogenicity and causation [30] an April 2016 report demonstrated that a causal relationship exists between prenatal ZIKV infection and microcephaly and other brain abnormalities [31]. Using a different methodology (Bradford-Hill criteria) [32], a study published February 2017 again came to the same conclusion [33].

The collection of anomalies that is both consistent and unique to pregnancies exposed to ZIKV is called Congenital Zika Syndrome (CZS). CZS includes severe microcephaly with a partially collapsed skull, thin cerebral cortices and subcortical calcifications, posterior ocular anomalies, congenital contractures, and neurologic sequelae including hypertonia 
[34]. Intrauterine growth restriction and low birth weight have also been reported [35].

French Polynesia data estimated the microcephaly risk at $1 \%$ of first-trimester-exposed fetuses, while an analysis of Brazil data estimates the first-trimester exposure microcephaly risk at $1-13 \%$ (depending on the true infection rate and whether there was over-reporting) [36]. Prospective cohort studies of ZIKV-exposed pregnant women in French Guiana and Brazil have reported central nervous system (CNS) ultrasound abnormality rates of $9 \%$ (vs. $4 \%$ in control) [37] and imaging or clinical abnormality rates of $42 \%$ (vs. $5 \%$ in control) [38], respectively.

The first report from the continental USA and Hawaii Zika Pregnancy Registry (USZPR) found birth defects in $6 \%$ of ZIKV-positive pregnancies, with similar percentages from symptomatic and asymptomatic patients [39]. Four percent of infants had microcephaly specifically, representing an approximately 30 -fold increase from baseline [40]. Of pregnant women with laboratory evidence of infection specifically in the first trimester, $11 \%$ reported birth defects potentially associated with ZIKV [39]. The sample size was more than doubled (from 442 to 972) in an updated USZPR report including pregnancies completed through December of 2016 and the finding of a $10 \%$ birth defect rate in ZIKV-affected pregnancies was covered in the popular media [41]. Indeed, in laboratory-confirmed ZIKV-infected mothers, $10 \%$ of infants (24/250) had birth defects associated with ZIKV. When all mothers were included, adding those with some evidence of recent flavivirus exposure (possible ZIKV infection) but not meeting CDC's definitions for confirmed ZIKV, the proportion was 5\% (51/972) [40]. Data on microcephaly alone were not released in this update. Of critical importance to clinicians providing guidance: the highest proportion of birth defects was in mothers infected in the first trimester with laboratoryconfirmed ZIKV: $9 / 60$, or $15 \%$, with a $95 \%$ confidence interval of 8 to $26 \%$ [40].

However, neurological risk is not exclusive to the first trimester. From Brazil, there have been two reported cases of neurologic abnormalities after exposure at 36 weeks [42], and the Brazilian prospective cohort study found $29 \%$ of pregnancies infected in the third trimester had adverse outcomes [38]. Neurological sequelae are not limited to microcephaly at birth. A case series of 13 non-microcephalic neonates born to ZIKVpositive mothers in Brazil described brain abnormalities associated with ZIKV: most also had head growth deceleration that led to postnatal microcephaly [43].

Whether miscarriage and intrauterine fetal demise are increased after ZIKV infection remains unknown; a case series has described three second-trimester miscarriages potentially associated with ZIKV infection [44] and the French Guiana prospective study found a statistically significant increase in IUFD after the second trimester in ZIKV-positive pregnant women compared with controls: $3 \%$ vs. $0.75 \%$ [37].

\section{In vitro, stem cell, animal models}

In the early stages of the ZIKV epidemic, there was uncertainty about the cause of the increased rate of microcephaly. "Fake news" stories initially claimed that the larvicide pyriproxyfen and its manufacturer were responsible for Brazil's microcephaly spike [45]. A zebrafish model exposed to pyriproxyfen found no CNS abnormalities, specifically examining neural stem cells, neural development, and brain volume [46].

ZIKV stem cell research has increased understanding and raised additional questions about viral pathogenesis [47]. Neural stem cells, neurospheres (model for very early neurogenesis) and brain organoids (model for neocortex development in the first trimester) derived from human-induced pluripotent stem cells infected by ZIKV demonstrated cell death, impaired formation, and reduced growth, respectively [48]. AXL, a member of the TAM family of transmembrane receptor proteins involved in phagocytosis, is a favored candidate receptor for ZIKV entry into cells. However, AXL ablation does not protect cerebral organoids from ZIKV infection, so entry into cells is not yet fully understood [49]. Firsttrimester human organ culture models found ZIKV replicates in maternal decidua, damages the placenta, and infects the early umbilical cord and its mesenchymal stem cells [50], while a similar model showed active replication in decidua and chorionic villi in the first trimester [51].

Mouse models have led to advances in the understanding of ZIKV [52]; however, immunocompetent mice infected peripherally with contemporary Asian ZIKV strains do not show effects, so immune modulation or bypass has been undertaken in various ways to model the human response. Some models have used African ZIKV strains adapted for mouse infectivity [53]; others have used interferon knockout models $[54,55]$ or interferon receptor-specific antibody [53], steroids [56], or direct injection of target organs [57, 58]. Specifically related to sexual transmission and fetal consequences of ZIKV, murine models have demonstrated male-to-female sexual transmission [59], that RNA persistence in semen outlasts infectivity [54], and that pregnant female mouse exposure to vaginal ZIKV led to fetal brain infection [55]. While Duggal et al. reported that vasectomy in their mouse model reduced infectious semen [54], the longest ZIKV has been cultured (69 days) in humans was in a vasectomized patient [15].

Testicular tropism of ZIKV to spermatogonia, spermatocytes, and Sertoli cells, as well as significant architectural damage and infertility, has been demonstrated in ZIKVinfected male mouse models [53, 56, 57]. Again, these mouse models are not immunocompetent; in one steroid-suppressed model, recombinant interferon reduced the histologic effect of ZIKV on the testes [56]. Whether ZIKV-associated testicular damage or infertility will be seen in nonhuman primates or in humans remains to be demonstrated. 
ZIKV has been demonstrated in the semen and testes of immunocompetent rhesus macaques $[60,61]$, but architectural damage to the testes has not been reported. Intravaginal and intrarectal inoculation with ZIKV has high infectivity in macaques [62]. Fetal transmission of ZIKV has been modeled in a pigtail macaque $(n=1)$, which was inoculated with multiple injections of a relatively high viral load; virus was detected in the fetal brain, and there was arrested brain growth [52]. Pregnant rhesus macaques $(n=4)$ showed highly efficient maternal-fetal transmission, with evidence of slowed head growth velocity [63].

A neutralizing human monoclonal antibody given to pregnant mice pre- or post-inoculation with Zika virus has been shown to reduce placental pathology, fetal brain infection, and fetal mortality [64]. Mouse models have been used to show protection from ZIKV in development of DNA vaccines [65, 66], a live-attenuated vaccine [67], and lipid nanoparticle-encapsulated nucleoside-modified messenger RNA (mRNA-LNP) vaccines [68, 69]. Chimeric ZIKVDENV viruses induced protection from ZIKV infection in a mouse model and may also be a candidate for vaccine development [70]. Several vaccines have shown protection against challenge in rhesus models, including a mRNALNP vaccine [68], purified inactivated virus, and DNAbased vaccines $[65,71]$.

Vaccine protection in pregnant models (mouse or nonhuman primate) has not been published. Based on animal model success, clinical trials in healthy nonpregnant human volunteers have begun, with several currently recruiting in the USA (continental: NCT02937233, NCT02952833, NCT02963909; PR: NCT02887482).

Vaccine development and antibody differentiation for flaviviruses are made more difficult by flavivirus crossreactivity. In vitro assays show antibody-dependent enhancement (ADE) of ZIKV from dengue antibodies, dengue being a related flavivirus with similar epitopes [72]. The hypothesized mechanism for ADE is that dengue antibodies which are not neutralizing may enable ZIKV to enter targeted cells for replication, leading to higher viral loads. In a murine model of ADE using dengue and West Nile virus convalescent serum, ZIKV viral loads have been found to be higher in the blood, spinal cord, and testes [73].

In vitro assays have been deployed to screen for therapeutic targets, both drugs already approved for human use for other indications as well as other compounds: Hamer et al. nicely review several of these studies as well as other aspects of ZIKV sexual transmission in their March 2017 publication [74]. Saiz et al. review investigations for ZIKV antivirals comprehensively; many drugs in current use have ZIKV-antiviral activity in cell culture, including unlikely ones such as sertraline and lovastatin [75].

\section{Guidelines}

\section{Zika testing}

Testing for ZIKV is done by molecular (RNA) or serologic (antibody) methods. In the USA, the Trioplex real-time RTPCR is a laboratory test designed to detect ZIKV, dengue virus, and chikungunya virus RNA. The test has not been cleared or approved by the Food and Drug Administration (FDA), but the use of this test has been authorized under an Emergency Use Authorization (EUA) [76]. Additional molecular tests (also referred to as nucleic acid tests (NAT)) have been granted EUA for ZIKV by itself [77]. The interpretation of molecular and serologic tests is not straightforward and guidance published by the CDC in May 2016 is useful for those who order and receive these test results [78]. Timing is critical in determining the appropriate test; if a pregnant patient presents within 2 weeks of exposure (by travel or sexual contact) or within 2 weeks of symptoms, RT-PCR of serum and urine is appropriate [79]. If testing is initiated after 2 weeks, ZIKV antibody (IgM) is the first step. ZIKV IgMELISA results can be positive, negative, equivocal, or inconclusive. A positive, equivocal, or inconclusive test should be followed up with a plaque reduction neutralization test (PRNT) to differentiate between the flaviviruses: by a 10fold higher ZIKV IgM titer than cross-reacting flavivirus antibodies [78]. However, PRNT is not always able to definitely identify the specific flavivirus, and for this reason, the test is not routinely recommended in Puerto Rico: dengue is endemic and likely to cause cross-reactivity in most cases [80]. The ubiquity of cross-reactive results makes PRNT less informative, also PRNT testing is resource intensive [81]. In pregnant women, RT-PCR is appropriate as a reflex test 2-12 weeks after exposure or symptoms if ZIKV IgM testing yields positive or equivocal results [79], as extended viremia up to 14 weeks has been seen in pregnancy [82]. While a positive RT-PCR molecular test for ZIKV confirms disease in a person suspected to have ZIKV, a negative result does not exclude it [78].

State health departments remain a critical link between providers and appropriate testing, but commercial tests are becoming more widely available [83]. The FDA EUAs for these tests specify that in the USA, commercial assays are only approved for patients meeting CDC testing criteria [77].

\section{Management of pregnancies at risk}

Pregnant women at risk for ZIKV by virtue of travel to countries with local mosquito-borne transmission or whose sexual partner has traveled to at-risk countries should be tested for ZIKV, as above and detailed by CDC guidelines updated July of 2016 [79]. Appropriate and timely testing is critical in order to anticipate risk to the fetus and needed evaluations after 
birth, enroll patients appropriately in Zika pregnancy registries, counsel patients on options regarding continuation of the pregnancy, and secure patients' access to resources that are made available to ZIKV-positive pregnancies (which have yet to be fully defined). In addition to testing of pregnant women with isolated exposure, women who live in areas with local ZIKV transmission or who otherwise have ongoing risk should have IgM antibody testing in the first and second trimesters as part of a routine obstetric management. Local health officials are charged with the decision to implement testing for all asymptomatic pregnant women in their jurisdiction, based on levels of ZIKV transmission and laboratory capacity [79].

Pregnant women who have been tested and have confirmed a possible or presumptive ZIKV infection should receive serial fetal ultrasounds (every 3-4 weeks) for growth and neuroanatomy (assessing for microcephaly, intracranial calcificiations, ventriculomegaly, arthrogryphosis, and abnormalities of the corpus callosum, cerebrum, cerebellum, and eyes). These women should also be enrolled in the appropriate ZIKV pregnancy registry: in the USA, this would be USZPR, the Puerto Rico Zika Active Pregnancy Surveillance System [79], and/or the international registry. Local health departments should facilitate enrollment in national registries, but the international registry is open to all health care providers and aims to anonymously enroll pregnant women at risk of ZIKV, at any gestational age, before testing, in a prospective manner [84].

Only pregnant patients who have had appropriate testing with evidence of no recent Zika infection are excluded from serial fetal ultrasounds; in this case, one routine prenatal screening ultrasound is still recommended, and if it shows fetal abnormalities consistent with CZS, repeat serologic and molecular testing is warranted [79]. At live birth or in the case of intrauterine fetal demise, placental pathology and testing for evidence of ZIKV infection is critical; this may provide the evidence confirming a possible ZIKV infection. The guidelines for testing of infants were updated in August 2016 [85]; adherence to these guidelines has not been universal and should be encouraged [40].

\section{Preconception counseling, prevention of sexual transmission, and ART}

The most relevant guidelines to an infertility specialist in the USA are those applicable to couples attempting reproduction. In September 2016, the WHO, CDC, and American Society for Reproductive Medicine (ASRM) each released their most recent guidelines for this population, with differences in emphasis and some differences in recommendations (Table 1). As more information is gathered regarding sexual transmission and the pathophysiology of ZIKV, these guidelines have been and will continue to be updated.
The WHO [86], CDC [87], and ASRM [88] all recommend patient education on the risks of ZIKV in pregnancy, discussion of safer sex practices, and access to reliable contraception including emergency contraception. As applied in the guidelines, sex includes vaginal sex, anal sex, oral sex, and the sharing of sex toys. Safer sex includes correct and consistent condom use for vaginal, anal, and oral sex and nonpenetrative sex, reducing the number of sexual partners and postponing sexual debut. Safer sex or abstinence throughout pregnancy is specifically recommended to couples where a female is pregnant and her partner has had potential ZIKV exposure (WHO, CDC) or ZIKV infection (ASRM, WHO, CDC).

Of the three, WHO guidelines are the most conservative in their recommendations for deferral of pregnancy after either potential exposure or a diagnosis of ZIKV infection. For women and men at risk or with disease, a 6-month deferral is recommended before attempting to conceive. The CDC likewise recommends a 6-month deferral if a male partner is at risk or diagnosed with the disease; however, if the partner desiring to conceive is a female at risk, an 8-week deferral is recommended. In contrast with the WHO and CDC, ASRM differentiates its recommendations for patients with diagnosed Zika versus potential exposure. Like WHO, ASRM recommends a 6-month deferral if either partner is diagnosed with ZIKV infection. One caveat is that ASRM recommendations were released just before the CDC updated its female guidelines from 6 months to an 8-week deferral.

For all men and women attempting reproduction and at risk of ZIKV but without clinical illness, the ASRM guidance advocates that routine testing for ZIKV by RT-PCR should be made available. At this time, such patients would not meet CDC criteria for testing; only pregnant women or patients with ZIKV symptoms meet criteria. ASRM further recommends testing within 2 weeks of possible exposure and 8 weeks later, deferring attempts to conceive until both tests are negative. For patients at risk of exposure, testing at the time of infertility treatment, quarantine of gametes, and serum testing 8 weeks later, before transfer is suggested by ASRM as a strategy for infertility centers to reduce the risk of transmission of ZIKV to a pregnancy. ASRM also suggests that semen cryopreservation before potential travel risk in a male partner attempting reproduction may reduce pregnancy risk. WHO and ASRM both cite concerns that RT-PCR testing of semen is not validated and do not recommend it routinely, at the time of guideline release.

Semen processing techniques, while effective in reducing the risk of transmission of HIV [89], should not be assumed to be effective in reducing ZIKV risk, ASRM cautions. A report of ZIKV RNA presence in the head of human sperm [90] raises concerns that processing may not remove ZIKV. Semen processing efficacy of human semen is the aim of a clinical trial in France that in December 2016 was no longer recruiting but had not yet published preliminary results (NCT02874456). 
Table 1 Guidelines for US couples to reduce Zika sexual transmission

\begin{tabular}{|c|c|c|c|}
\hline Targeted populations & WHO guidance & CDC guidance & ASRM guidance \\
\hline $\begin{array}{l}\text { All reproductive age men and women, } \\
\text { including attempting and not attempting } \\
\text { to conceive }\end{array}$ & \multicolumn{3}{|c|}{$\begin{array}{l}\text {-Zika risk counseling (risk of microcephaly in prenatal exposure) } \\
\text {-Safer sex counseling (risk of sexual transmission, barrier methods) } \\
\text {-Contraception counseling (most effective and emergency contraception) }\end{array}$} \\
\hline \multicolumn{4}{|c|}{ Men and women attempting to conceive, with or without infertility treatment and... } \\
\hline Travel risk of exposure & $\begin{array}{l}\text { Defer pregnancy } 6 \text { months }{ }^{\mathrm{a}} \\
\text { if either partner at risk }\end{array}$ & $\begin{array}{l}\text { Male at risk: defer pregnancy } \\
\text { for } 6 \text { months } \mathrm{s}^{\mathrm{a}} \\
\text { Female at risk: defer pregnancy } \\
\text { for } 8 \text { weeks }\end{array}$ & $\begin{array}{l}\text { Before attempt: negative serum RT-PCR } \\
\text { within } 2 \text { weeks }^{\mathrm{a}} \text { and } 8 \text { weeks later }\end{array}$ \\
\hline Zika disease & $\begin{array}{l}\text { Defer pregnancy for } \\
6 \text { months } s^{\mathrm{a}} \text { if either partner } \\
\text { is diagnosed }\end{array}$ & $\begin{array}{l}\text { Male diagnosed: defer } \\
\text { pregnancy for } 6 \text { months }{ }^{\mathrm{a}} \\
\text { Female diagnosed: defer } \\
\text { pregnancy for } 8 \text { weeks }\end{array}$ & $\begin{array}{l}\text {-Defer pregnancy for } 6 \text { months }{ }^{\mathrm{a}} \\
\text {-Consider retesting serum RT-PCR before } \\
\text { deferred attempt if initially positive }\end{array}$ \\
\hline Local risk of exposure & Informed choice & $\begin{array}{l}\text { Undergo testing; if positive, } \\
\text { follow Zika disease } \\
\text { recommendations }\end{array}$ & Defer pregnancy until risk is minimal \\
\hline Pregnant women & \multicolumn{2}{|c|}{$\begin{array}{l}\text { Safer sex or abstain throughout pregnancy if male or female } \\
\text { sexual partner is at risk or had Zika disease }\end{array}$} & $\begin{array}{l}\text { Safer sex or abstain throughout } \\
\text { pregnancy if male or female sexual } \\
\text { partner has positive } \\
\text { test or Zika disease }\end{array}$ \\
\hline Gamete donors & \multicolumn{2}{|l|}{ No comment } & $\begin{array}{l}\text { Exclude as donor if, in past } 6 \text { months, } \\
\text { person had: } \\
\text {-Zika disease } \\
\text {-Travel or local risk } \\
\text {-Sex with a partner who meets } 1 \text { of the } \\
\text { other criteria }\end{array}$ \\
\hline
\end{tabular}

${ }^{\mathrm{a}}$ Time from symptom onset or last time of exposure risk

Guidelines for assisted reproduction in patients and providers vary by country. Brazil's initial regulatory guidelines published March 2016 required negative Zika testing (serologic) within 5 days of gamete collection [91], which was reportedly found to be difficult, since serologic testing often took 7 days and RT-PCR was not always available [92]. The French guidelines were first published February 2016 and last updated in January 2017: they recommend waiting 2 months after potential ZIKV exposure or 2 months after a local epidemic is officially over before infertility treatment. In addition to serologic testing, RT-PCR testing of semen has a critical role in French decision-making algorithms for assisted reproduction. If any prior tests for ZIKV, including semen RTPCR, suggest infection in the male partner, only semen that has been tested ZIKV negative by RT-PCR (requiring cryopreservation of the remaining sample while testing is completed) is recommended to be used for ART [93]. It was in adherence to French ZIKV-ART guidelines that the first asymptomatic transmission of ZIKV from male to female was reported [14].

\section{Gamete donation}

FDA guidelines published in March 2016 recommend that potential gamete donors be considered ineligible if they have had a medical diagnosis of ZIKV infection in the past 6 months, if they have had possible exposure by travel or residence in an area with local ZIKV transmission in the past 6 months, or if they, in the past 6 months, have had sex with a male at risk or diagnosed with ZIKV in the 6 months prior to sexual contact [94]; ASRM echoes this guidance. At issue are similar concerns that led to the FDA's recommendation in August 2016 to use the EUA Zika NATs for all blood donors: donors may be asymptomatic or not know they were in a geographic area of risk. Use of donor gametes or embryos collected prior to screening question implementation, and even afterward, do not have a zero risk of ZIKV, and patient consent should reflect awareness of this uncertainty. Highlighting this risk is the March 2017 CDC update encouraging sperm donor recipients from Southern Florida donors be made aware of increased risk [95]. With additional information gathered, it seems that local transmission may not have been restricted to Miami-Dade counties in Florida, and that nearby Broward and Palm Beach counties were also at risk in the summer of 2016.

\section{Effects of guidelines on ART practice}

The infertile population by definition has had their ideal pregnancy timing deferred by biological circumstance. To recommend or require these couples to defer pregnancy further is no 
easy task, and in some cases, waiting 6 months may affect the chances of a couple conceiving, particularly in women of advanced reproductive age. So an important question is whether guidelines have resulted in delays in ART treatment. A Brazilian ART clinic reported delays for five cases (the denominator was unclear: 68-152), and the cost of testing couples was equivalent to 1.2 days of in vitro fertilization (IVF) stimulation costs [96].

Although the chances of infection will vary by whether a patient is at risk of local transmission or travel risk, the worst case scenario of not deferring infertility treatment is concrete. A recent report documented the first case of microcephaly in a fetus conceived by IVF [97]. In this case, the French couple living in Venezuela underwent IVF for infertility, achieved a singleton pregnancy, then at 10 weeks the woman presented with ZIKV symptoms and had positive ZIKV RT-PCR. Ultrasounds at 12 and 14 weeks were normal; at 19 weeks, there was isolated microcephaly. Additional brain abnormalities were detected at 21 weeks, and the pregnancy was terminated at 24 weeks. If the patient had stayed in Venezuela, she would not have had access to abortion services.

\section{Role of the infertility specialist (Box 1)}

\section{Educate}

Whether infertility patients are trying to conceive or are newly pregnant, education regarding ZIKV is relevant to reduce their risk of having a pregnancy affected by the threat of congenital anomaly. Specific areas of patient ZIKV knowledge should be addressed: why it is important to them, who is at risk, how it can be prevented, what symptoms are, and how testing should be accomplished. Perhaps the most critical number to relate to patients is the fetal brain anomaly risk of $15 \%$ when labconfirmed ZIKV infection occurs in the first trimester [40]. Besides avoiding travel to known regions of transmission, mosquito bite avoidance is the only preventative strategy for vectoracquired ZIKV. Recent research suggests DEET is more effective than picardin at preventing mosquito bites and that ZIKV infection does not affect mosquito response to repellents [98].

Patient handouts and posters are available through the CDC, American Congress of Obstetricians and Gynecologists (ACOG), and other entities. The CDC specifically permits redistribution of its materials with appropriate citation. The CDC has print materials (114 unique ZIKV-related items as of 21 Apr 2017) in multiple languages (up to 13, most have at least English, Spanish, and Portuguese) targeted to specific populations (including travelers, pregnant women, LGBT persons, health care providers) and prevention/testing strategies (including areas at risk, mosquito bite prevention, safer sex strategies) [99].

Practice websites and social media accounts have been used by a minority of obstetric clinics to disseminate information about ZIKV [100]; infertility clinic websites and social
Box 1 What can infertility specialists do about Zika virus?

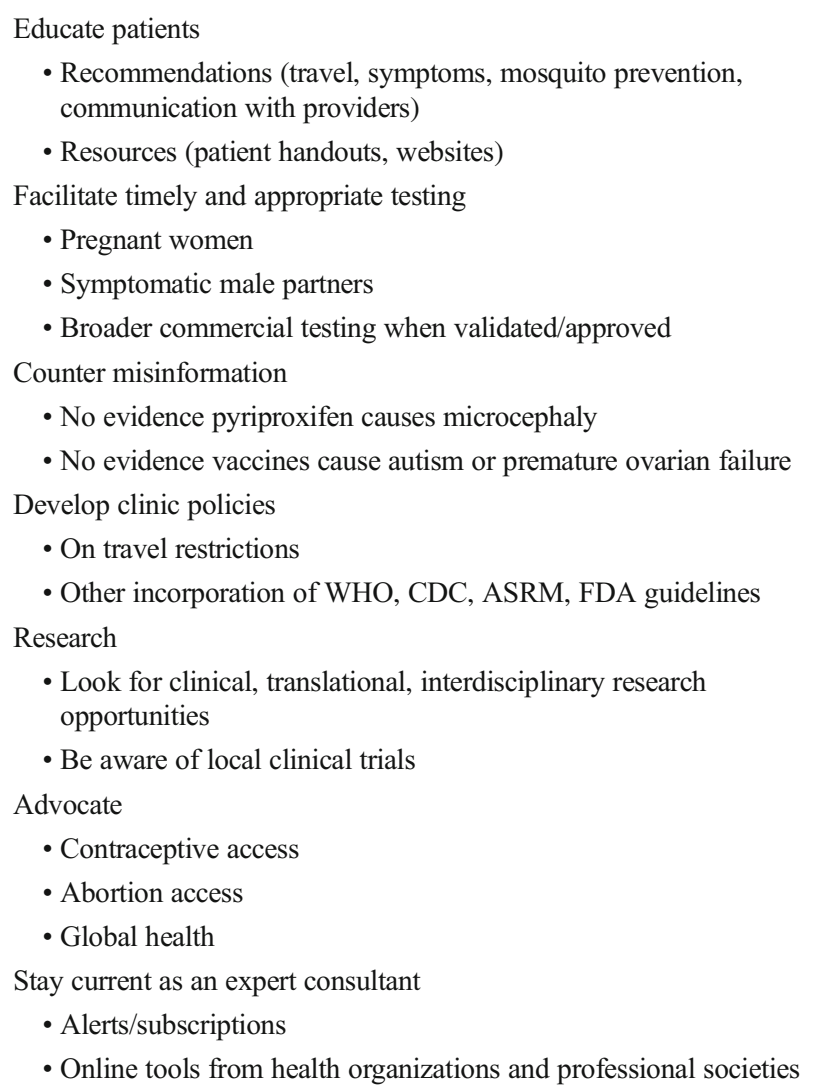

media accounts can and have provided similar information, though the prevalence of this is not quantified. Infertility practices should be aware that Mothertobaby.org is a valuable resource for both patients and clinicians, for all teratogens including ZIKV [101].

\section{Facilitate timely, appropriate testing}

Timely, appropriate testing is of critical importance to accurate diagnosis of ZIKV and appropriate follow-up. Unfortunately, testing is complicated, and appropriate testing is not being completed universally: one particularly disheartening example of this is the $12 \%$ of infants with birth defects and $41 \%$ of all 442 completed pregnancies in the US Zika Pregnancy Registry that did not have testing of fetal or infant samples [39]. Referencing testing guidelines, using algorithms developed by the CDC, and knowing your health department contacts will be of assistance, but patient awareness and acceptance of testing recommendations are also potential critical factors.

Testing is also a limited resource: right now testing in the USA is only FDA approved for specific persons at risk, namely pregnant women and symptomatic travelers at risk. Absent from these populations are the asymptomatic men and women 
travelers at risk trying to become pregnant or not preventing pregnancy.

\section{Counter misinformation}

In the current Information Age, infertility patients are often widely read and up to date with aspects of the literature, but this also exposes them to potential misinformation. Of particular harm to reproductive-age persons are the false and unsubstantiated reports of a link between pyriproxyfen and microcephaly as well as "anti-vax" propaganda. One recent, relevant example of this misinformation is the January 2016 position statement from the American College of Pediatricians (which is not the American Academy of Pediatrics) that "(HPV vaccination) could possibly be associated with the very rare but serious condition of premature ovarian failure," while admitting that "there is no strong evidence of a causal relationship between HPV4 and ovarian dysfunction" [102]. The American Academy of Pediatrics has online resource documenting the evidence that there is no link between autism and the Measles-Mumps-Rubella vaccination [103]. Fear of vaccines could impact the acceptance of an as-yet-unapproved ZIKV vaccine; countering vaccine misinformation is not just the role of pediatricians. Geography, education, and age will likely contribute to vaccine acceptance, but a survey in mid2016 found that 53\% (327/619) of Virginia University students would likely get a ZIKV vaccine when available [104].

\section{Develop clinic/laboratory policies}

Until testing of semen and other genital fluids is validated, or routine serum screening is feasible, keeping ZIKV out of the lab is primarily a function of clinical screening of patients at risk. While the FDA has not yet made recommendations outside of donor tissue screening, a review published in September of 2016 includes the following lab-specific suggestions that are not found in CDC, FDA, or ASRM guidelines: use a ZIKV risk screening questionnaire for all patients undergoing infertility treatment and all men submitting semen samples to the lab; if CDC guidelines are not followed after extensive counseling, the specimen should be labeled and stored separately reflecting potential increased risk, and if liquid nitrogen is required, open carriers should not be used; and, perhaps the most radical suggestion, "If we are not able to generate effective measures against ZIKV in a timely fashion, we may need to consider cryopreservation of screened specimens (gametes and embryos) for all couples residing in endemic areas" [105]. This Washington et al. review was published before the mouse studies suggested testicular damage by ZIKV: to build on their suggestion, we may in the future be recommending fertility preservation of male specimens for both infectious and infertility risk, if murine findings are replicated in male humans.
Clinic and lab policies must be made considering several factors with many unknowns. If an infertility clinic switches from advising patients of the risk of ZIKV to directing [106] that infertility treatment will be deferred unless CDC guidelines are followed, this raises the question: will patients seek other facilities for treatment? Infertility treatment providers must consider the risks of lower volume against the risks of laboratory contamination and liability of helping a couple at risk of ZIKV achieve a pregnancy.

\section{Advocate}

By reducing unintended pregnancies, enhanced contraception access in the USA is modeled to reduce microcephalic births from ZIKV by $16 \%$ [107]. Increasing access to contraception in Puerto Rico during the ZIKV outbreak, projected to cost $\$ 33.5$ million, was estimated to potentially reduce ZIKVrelated costs by $\$ 65.2$ million. There are limitations to these projections, but multiple sensitivity analyses of alternate scenarios still yielded cost-effectiveness, if not cost-savings [108]. By June of 2016, 56\% of Brazilian women reported avoiding or trying to avoid pregnancy due to ZIKV concerns [109]. However, contraceptive sales in Brazil showed little variation over the 2-year period before and after ZIKVassociated microcephaly warnings; condom use was not examined and long acting reversible contraceptive representation was very low [110].

Advocating for contraception access and abortion access could have a very real impact on the long-term effects of ZIKV and microcephaly. This is an uphill battle in the USA and globally [111]. As reproductive endocrinology specialists and advocates for women's health and reproductive choice, we have a duty and an opportunity to make our voices heard.

\section{Stay current}

ZIKV has been a hot topic over the past year, and the pace of research and discovery makes reviews such as this one outdated by the time they are e-published. What follows are some suggestions for staying up-to-date with ZIKV and could be applied to other topics of particular interest.

Download and subscribe Professional societies and health organizations such as ACOG, ASRM, WHO, CDC, and state health departments are disseminating ZIKV news via e-mail, Facebook, and Twitter platforms, RSS feeds, and on their website homepages. Journals use similar avenues for dissemination. Use an RSS reader app such as Feedly, Newsblur, or Inoreader to keep track of what the popular and professional media are saying about ZIKV. Create a "search alert," "document citation alert," or "author alert" using the various platforms of Pubmed, Scopus, Web of Science, and Google Scholar to be notified of newly published articles. The WHO 
ZIKV smartphone app organizes its information into: General Information (key facts, symptoms, timeline), Health Care Workers (including all WHO bulletins), and News (including situation reports).

Online tools and resources The $\mathrm{CDC}$ has released a 46-page pdf "toolkit" with guidance, algorithms, and factsheets targeted for use by obstetricians [112]. The CDC has published widgets (app-like algorithm programs designed to be embedded in web pages) for the general population called "Know Your Zika Risk" and for providers called "Pregnancy and Zika Testing" [113]. The ACOG "toolkit" is one website that includes the CDC's Pregnancy and Zika Testing Widget, as well as a linkable patient information video, links to infographics, and state contacts for testing and registry [114]. ASRM published in April 2016 the "Zika Virus Guidance for Reproductive Care" eLearn activity, which is free for members.

Maps The CDC publishes several maps including an interactive world map [115] and US maps including detailed maps of locally acquired case areas [116]. The PAHO map is interactive and links to detailed ZIKV country reports for countries in the Americas [117]. HealthLandscape is a US map of travelassociated and locally acquired cases, with overlays including percent change from the previous week [118]. HealthMap is an interactive worldwide map/timeline of media and health organization reports [119].

WHO published a classification scheme for countries' ZIKV risk March 2017 [120]; this has not been incorporated into maps of risk areas so far but will be updated in future situation reports. The WHO classification describes four classes: class 1 is newly introduced, ongoing transmission area for ZIKV. Class 3 has a history of transmission, now interrupted, but future risk remains. Class 2 is anything that falls between class 1 and class 3 . Class 4 has no history of transmission, but a competent vector exists therefore there is potential for future risk.

\section{Research}

The intersection of sexual transmission and pregnancy risk overlaps significantly with field of reproductive endocrinology and infertility. Many questions remain unanswered or partially answered about ZIKV, particularly in reproductive health and regarding sexual transmission of the virus. Several articles have highlighted these questions, specifically Gornet et al. in September 2016 [121], Baud et al. in December 2016 [122], and Hamer et al. in March 2017 [74]: a summary of their questions and our own are highlighted in Box 2. Translational research can be enhanced by collaboration between basic and clinical scientists. Opportunities exist
Box 2 ZIKV sexual transmission and reproduction research questions

Tropism and viral kinetics of ZIKV in humans (male and female)

-Which reproductive cells and tissues are permissive to ZIKV replication? (sperm, spermatagonia, Sertoli cells, leukocytes; testes, epididymis, seminal vesicles, prostate; oocytes, oogonia, granulosa/theca cells; ovary, endometrium, cervix, vagina; embryo, fetus, placenta)

- Which genital fluids demonstrate ZIKV RNA? (semen, prostatic fluid, follicular fluid, cervical mucus, vaginal secretions)

- How long can ZIKV be demonstrated in fluids and tissues (acute, chronic phases)

- Is viral load and duration in fluids the same if asymptomatic? If previous flavivirus infection?

- Is ZIKV secreted into genital fluids intermittently?

- Are immunosuppressed or HIV+ individuals more likely to become chronic carriers?

- Does concurrent sexually transmitted infection increase shedding of ZIKV in genital fluids?

- Is persistence associated with co-infection, age, symptoms, viremia?

Infectivity of ZIKV in genital fluids (male and female)

- How long after infection are genital fluids infectious?

- How long after secretion do genital fluids remain infectious?

- Do sperm, oocytes, embryos actively or passively uptake ZIKV from infected seminal fluid?

Risks of transmission and cellular target by route

- Deep kissing? Orogenital sex? Vaginal sex? Anal sex?

Does sexual transmission differ from mosquito transmission regarding

- Targets of infection?

- Reproductive organs affected by direct inoculation/ascending infection or through viremia?

- Viral kinetics and tropism?

- Potential for Congenital Zika Syndrome?

Effects on adult reproductive organs

- Acute impact on sperm parameters?

- Long term impact on spermatogenesis?

- Acute or long term impact on testosterone/gonadotropin production?

- Acute or long term prostatitis, epididymitis, orchitis?

- Are tissue effects mediated by antibody-dependent enhancement?

Effects on fetal reproductive organs

- Tropism for fetal testis/ovary?

- Dysfunctional gonadal development?

- Chronically infected/infectious offspring?

Testing genital fluids for ZIKV

- Can RT-PCR be validated on genital fluids?

- What should criteria be for testing: Risk and a pregnant partner? Symptoms, risk, and trying

to conceive? Risk and trying to conceive? Differ by gender?

- When should genital fluids be tested?

- When should tests be repeated after a positive or negative result?

-Which male samples should be tested: Whole semen? Washed semen? Banked/thawed semen?

-Which female samples should be tested: Vaginal secretions? Cervical mucus? Endocervical sample or Pap? Follicular fluid?

Minimizing risk of transmission in infertility treatment/assisted reproductive technologies

- Could sperm washing/ICSI eliminate ZIKV?

- Could cryopreservation (conventional, vitrification, with antiviral agent) destroy ZIKV?

- Likelihood of liquid nitrogen contamination (closed/open systems)?

- Optimal screening of sperm and oocytes?

-Which gametes should be handed as potentially infectious and how?

-Who should bank gametes for (noninfectious) fertility preservation: Males vs males and females? Travelers? States most at risk for local mosquito transmission?

Treatments for ZIKV

-What animal models may be useful for trials of treatments to reduce sexual transmission/reproductive effects?

- What drugs, antibodies, or other treatment will reach reproductive organ sites of viral persistence? 
to contribute to answering these questions from the perspective of a reproductive endocrinologist.

As Richardson suggests, ZIKV risks may have an impact on women's leadership in global health [123]; a parallel may be suggested regarding ZIKV bench or clinical research. While the risk of occupational exposure to ZIKV in a research lab should be quite low, there has been at least one documented case in the USA from a needlestick injury in a research lab [27]. It is plausible that female scientists and technicians could be deterred by their own or others' concern of risk or litigation from pursuing research questions or positions that could expose them to ZIKV. However, reproductive age males may too be deterred, as they harbor the risk of sexual transmission longer and may (unlikely, but potentially) be at risk for testicular damage. Researchers should facilitate awareness of appropriate precautions and of how ZIKV risk affects participation.

\section{Conclusion}

Understanding the ongoing threat of ZIKV, particularly sexual transmission and risk to fetuses, remains highly relevant to infertility specialists. The infertility patient population is enriched with those targeted by WHO, CDC, and ASRM guidelines to reduce ZIKV sexual transmission. Reproductive endocrinologists are uniquely positioned to have an impact in preventing ZIKV transmission and sequelae through education, research, and advocacy.

As of 7 June 2017, there have been 5011 travel-associated cases in US states [124]. Locally transmitted cases have been reported: 218 in Florida and 6 in Texas. Based on genomic epidemiology, at least four introductions - but potentially as many as 40 - contributed to the local transmission in Florida, and local transmission likely started several months before initial detection [125]. Also, initial estimates of local transmission in Florida were modified with additional information reported 9 months later [95]. The virus' competent vectors are present in much of the USA, including Oklahoma in 2016 [126]. In other relatively naïve geographies with large populations at risk: ZIKV-competent vectors are present in China [127], and India recently documented its first ZIKV cases [128], a country which struggled to contain past dengue epidemics [129]. While public health efforts were successful in preventing widespread local transmission in the USA in 2016 [130], this does not guarantee safety in the future of a fragmented and polarized public health climate [131] and delayed vigilance could have devastating consequences. With continued potential for outbreaks during the upcoming mosquito season in the USA, providers need to be prepared to help counter the threat ZIKV poses on public health.

\section{Compliance with ethical standards}

Conflict of interest The authors declare no conflict of interest.

\section{References}

1. World Health Organization. WHO statement on the first meeting of the International Health Regulations. (IHR 2005) Emergency Committee on Zika virus and observed increase in neurological disorders and neonatal malformations. 2016. http://www.who.int/ mediacentre/news/statements/2016/1st-emergency-committeezika/en/. Accessed 21 Apr 2017, 2005.

2. World Health Organization. Fifth meeting of the Emergency Committee under the International Health Regulations (2005) regarding microcephaly, other neurological disorders and Zika virus, 2016. http://www.who.int/mediacentre/news/statements/ 2016/zika-fifth-ec/en/. Accessed 21 Apr 2017.

3. Musso D, Gubler DJ. Zika Virus. Clin Microbiol Rev. 2016;29(3): 487-524. doi:10.1128/cmr.00072-15.

4. Duffy MR, Chen TH, Hancock WT, Powers AM, Kool JL, Lanciotti RS, et al. Zika virus outbreak on Yap Island, Federated States of Micronesia. N Engl J Med. 2009;360(24):2536-43. doi: 10.1056/NEJMoa0805715.

5. Gallian P, Cabie A, Richard P, Paturel L, Charrel RN, Pastorino B, et al. Zika virus in asymptomatic blood donors in Martinique. Blood. 2017;129(2):263-6. doi:10.1182/blood-2016-09-737981.

6. Aubry M, Teissier A, Huart M, Merceron S, Vanhomwegen J, Roche C, et al. Zika virus Seroprevalence, French Polynesia, 2014-2015. Emerg Infect Dis. 2017;23(4):669-72. doi:10.3201/ eid2304.161549.

7. World Health Organization. Zika virus disease: interim case definitions, 2016. http://apps.who.int/iris/bitstream/10665/204381/1/ WHO_ZIKV_SUR_16.1_eng.pdf. Accessed 28 Apr 2017.

8. Centers for Disease Control and Prevention. When to test for Zika virus, 2016. https://www.cdc.gov/zika/pdfs/when-to-test-zika.pdf. Accessed 21 Apr 2017.

9. Oklahoma State Department of Health. Zika and other travelassociated arboviral diseases screening and evaluation guidance, 2016. https://www.ok.gov/health2/documents/Zika\% 20Clinician\%20Packet.pdf. Accessed 21 Apr 2017.

10. Grischott F, Puhan M, Hatz C, Schlagenhauf P. Non-vector-borne transmission of Zika virus: a systematic review. Travel Med Infect Dis. 2016;14(4):313-30. doi:10.1016/j.tmaid.2016.07.002.

11. Moreira J, Peixoto TM. Machado de Siqueira A, Lamas CC. Sexually acquired Zika virus: a systematic review. Clinical Microbiology and Infection: the Official Publication of the European Society of Clinical Microbiology and Infectious Diseases. 2017; doi:10.1016/j.cmi.2016.12.027.

12. Foy BD, Kobylinski KC, Chilson Foy JL, Blitvich BJ. Travassos da Rosa A, Haddow AD et al. Probable non-vector-borne transmission of Zika virus, Colorado, USA. Emerg Infect Dis. 2011;17(5):880-2. doi:10.3201/eid1705.101939.

13. Turmel JM, Abgueguen P, Hubert B, Vandamme YM, Maquart M, Le Guillou-Guillemette H, et al. Late sexual transmission of Zika virus related to persistence in the semen. Lancet (London, England). 2016;387(10037):2501. doi:10.1016/s0140-6736(16) 30775-9.

14. Freour T, Mirallie S, Hubert B, Splingart C, Barriere P, Maquart $M$, et al. Sexual transmission of Zika virus in an entirely asymptomatic couple returning from a Zika epidemic area, France, April 2016. Euro Surveillance: Bulletin Europeen Sur Les Maladies Transmissibles $=$ European Communicable Disease Bulletin. 2016;21(23) doi:10.2807/1560-7917.es.2016.21.23.30254.

15. Arsuaga M, Bujalance SG, Diaz-Menendez M, Vazquez A, Arribas JR. Probable sexual transmission of Zika virus from a vasectomised man. Lancet Infect Dis. 2016;16(10):1107. doi:10. 1016/s1473-3099(16)30320-6.

16. Nicastri E, Castilletti C, Liuzzi G, Iannetta M, Capobianchi MR, Ippolito G. Persistent detection of Zika virus RNA in semen for six 
months after symptom onset in a traveller returning from Haiti to Italy, February 2016. Euro Surveillance: Bulletin Europeen Sur Les Maladies Transmissibles = European Communicable Disease Bulletin. 2016;21(32) doi:10.2807/1560-7917.es.2016. 21.32.30314.

17. Wu D, Sun J, Zhong H, Guan D, Zhang H, Tan Q, et al. A family cluster of imported ZIKV cases: viremia period may be longer than previously reported. The Journal of Infection. 2016;73(3): 300-3. doi:10.1016/j.jinf.2016.06.008.

18. Paz-Bailey G, Rosenberg ES, Doyle K, Munoz-Jordan J, Santiago GA, Klein L, et al. Persistence of Zika virus in body fluids preliminary report. N Engl J Med. 2017; doi:10.1056/ NEJMoa1613108.

19. Atkinson B, Thorburn F, Petridou C, Bailey D, Hewson R, Simpson AJ, et al. Presence and persistence of Zika virus RNA in semen, United Kingdom, 2016. Emerg Infect Dis. 2017;23(4) doi:10.3201/eid2304.161692.

20. Barzon L, Pacenti M, Franchin E, Lavezzo E, Trevisan M, Sgarabotto D, et al. Infection dynamics in a traveller with persistent shedding of Zika virus RNA in semen for six months after returning from Haiti to Italy, January 2016. Euro Surveillance: Bulletin Europeen Sur Les Maladies Transmissibles = European Communicable Disease Bulletin. 2016;21(32) doi:10.2807/15607917.es.2016.21.32.30316.

21. Froeschl G, Huber K, von Sonnenburg F, Nothdurft HD, Bretzel $\mathrm{G}$, Hoelscher M, et al. Long-term kinetics of Zika virus RNA and antibodies in body fluids of a vasectomized traveller returning from Martinique: a case report. BMC Infect Dis. 2017;17(1):55. doi:10.1186/s12879-016-2123-9.

22. Visseaux B, Mortier E, Houhou-Fidouh N, Brichler S, Collin G, Larrouy L, et al. Zika virus in the female genital tract. Lancet Infect Dis. 2016;16(11):1220. doi:10.1016/s1473-3099(16) 30387-5.

23. Zambrano H, Waggoner J, Leon K, Pinsky B, Vera K, Schettino $\mathrm{M}$, et al. High incidence of Zika virus infection detected in plasma and cervical cytology specimens from pregnant women in Guayaquil, Ecuador. American Journal of Reproductive Immunology (New York, NY: 1989). 2017;77(2) doi:10.1111/aji. 12630.

24. Jimenez A, Shaz BH, Bloch EM. Zika virus and the blood supply: what do we know? Transfus Med Rev. 2017;31(1):1-10. doi:10. 1016/j.tmrv.2016.08.001.

25. Galel SA, Williamson PC, Busch MP, Stanek D, Bakkour S, Stone $\mathrm{M}$, et al. First Zika-positive donations in the continental United States. Transfusion. 2017; doi:10.1111/trf.14029.

26. Williamson PC, Linnen JM, Kessler DA, Shaz BH, Kamel H, Vassallo RR, et al. First cases of Zika virus-infected US blood donors outside states with areas of active transmission. Transfusion. 2017; doi:10.1111/trf.14041.

27. Walker WL, Lindsey NP, Lehman JA, Krow-Lucal ER, Rabe IB, Hills SL, et al. Zika virus disease cases - 50 states and the District of Columbia, January 1-July 31, 2016. MMWR Morb Mortal Wkly Rep. 2016;65(36):983-6. doi:10.15585/mmwr.mm6536e5.

28. Dupont-Rouzeyrol M, Biron A, O'Connor O, Huguon E, Descloux E. Infectious Zika viral particles in breastmilk. Lancet (London, England). 2016;387(10023):1051. doi:10.1016/s01406736(16)00624-3.

29. Pfaender S, Vielle NJ, Ebert N, Steinmann E, Alves MP, Thiel V. Inactivation of Zika virus in human breast milk by prolonged storage or pasteurization. Virus Res. 2017;228:58-60. doi:10. 1016/j.virusres.2016.11.025.

30. Shepard TH. "proof" of human teratogenicity. Teratology. 1994;50(2):97-8. doi:10.1002/tera.1420500202.

31. Rasmussen SA, Jamieson DJ, Honein MA, Petersen LR. Zika virus and birth defects-reviewing the evidence for causality. $\mathrm{N}$
Eng1 J Med. 2016;374(20):1981-7. doi:10.1056/ NEJMsr1604338.

32. Hill AB. THE ENVIRONMENT AND DISEASE: ASSOCIATION OR CAUSATION? Proceedings of the Royal Society of Medicine. 1965;58:295-300.

33. Awadh A, Chughtai AA, Dyda A, Sheikh M, Heslop DJ, MacIntyre CR. Does Zika virus cause microcephaly - applying the Bradford Hill viewpoints. PLoS Currents. 2017;9 doi:10. 1371/currents.outbreaks.2fced6e886074f6db162a00d4940133b.

34. Moore CA, Staples JE, Dobyns WB, Pessoa A, Ventura CV, Fonseca EB, et al. Characterizing the pattern of anomalies in congenital Zika syndrome for pediatric clinicians. JAMA Pediatr. 2017;171(3):288-95. doi:10.1001/jamapediatrics.2016.3982.

35. Besnard M, Eyrolle-Guignot D, Guillemette-Artur P, Lastere S, Bost-Bezeaud F, Marcelis L, et al. Congenital cerebral malformations and dysfunction in fetuses and newborns following the 2013 to 2014 Zika virus epidemic in French Polynesia. Euro Surveillance: Bulletin Europeen Sur Les Maladies Transmissibles = European Communicable Disease Bulletin. 2016;21(13) doi:10. 2807/1560-7917.es.2016.21.13.30181.

36. Johansson MA, Mier-y-Teran-Romero L, Reefhuis J, Gilboa SM, Hills SL. Zika and the risk of microcephaly. N Engl J Med. 2016;375(1):1-4. doi:10.1056/NEJMp1605367.

37. Leo P, Gustavo M, Guillaume B, Gabriel C, Yves V, Dominique R, et al. Association between Zika virus and foetopathy: a prospective cohort study in French Guiana. Preliminary report. Ultrasound in Obstetrics \& Gynecology: the Official Journal of the International Society of Ultrasound in Obstetrics and Gynecology. 2017; doi:10.1002/uog.17404.

38. Brasil P, Pereira JP Jr, Moreira ME, Ribeiro Nogueira RM, Damasceno L, Wakimoto M, et al. Zika virus infection in pregnant women in Rio de Janeiro. N Engl J Med. 2016;375(24):2321-34. doi:10.1056/NEJMoa1602412.

39. Honein MA, Dawson AL, Petersen EE, Jones AM, Lee EH, Yazdy MM, et al. Birth defects among fetuses and infants of US women with evidence of possible Zika virus infection during pregnancy. JAMA. 2016; doi:10.1001/jama.2016.19006.

40. Reynolds MR, Jones AM, Petersen EE, Lee EH, Rice ME, Bingham A, et al. Vital signs: update on Zika virus-associated birth defects and evaluation of all U.S. infants with congenital Zika virus exposure - U.S. Zika pregnancy registry, 2016. MMWR Morb Mortal Wkly Rep. 2017;66(13):366-73. doi:10. 15585/mmwr.mm6613e1.

41. Belluck P. Birth defects are found in $10 \%$ of U.S. babies born to mothers infected with Zika. New York: The New York Times; 2017.

42. Soares de Souza A, Moraes Dias C, Braga FD, Terzian AC, Estofolete $\mathrm{CF}$, Oliani AH, et al. Fetal infection by Zika virus in the third trimester: report of 2 cases. Clinical Infectious Diseases: an Official Publication of the Infectious Diseases Society of America. 2016;63(12):1622-5. doi:10.1093/cid/ciw613.

43. van der Linden V, Pessoa A, Dobyns W, Barkovich AJ, Junior HV, Filho EL, et al. Description of 13 infants born during October 2015-January 2016 with congenital Zika virus infection without microcephaly at birth - Brazil. MMWR Morb Mortal Wkly Rep. 2016;65(47):1343-8. doi:10.15585/mmwr.mm6547e2.

44. Schaub B, Monthieux A, Najihoullah F, Harte C, Cesaire R, Jolivet E, et al. Late miscarriage: another Zika concern? Eur J Obstet Gynecol Reprod Biol. 2016;207:240-1. doi:10.1016/j. ejogrb.2016.10.041.

45. Snopes.com. Fact check: Zika microcephaly outbreak caused by Monsanto pesticide? 2016. http://www.snopes.com/zikamicrocephaly-outbreak-pesticide/. Accessed 21 Apr 2017.

46. Dzieciolowska S, Larroque AL, Kranjec EA, Drapeau P, Samarut E. The larvicide pyriproxyfen blamed during the Zika virus 
outbreak does not cause microcephaly in zebrafish embryos. Sci Rep. 2017;7:40067. doi:10.1038/srep40067.

47. Ming GL, Tang H, Song H. Advances in Zika virus research: stem cell models, challenges, and opportunities. Cell Stem Cell. 2016;19(6):690-702. doi:10.1016/j.stem.2016.11.014.

48. Garcez PP, Loiola EC, Madeiro da Costa R, Higa LM, Trindade P, Delvecchio R, et al. Zika virus impairs growth in human neurospheres and brain organoids. Science (New York, NY). 2016;352(6287):816-8. doi:10.1126/science.aaf6116.

49. Wells MF, Salick MR, Wiskow O, Ho DJ, Worringer KA, Ihry RJ, et al. Genetic ablation of AXL does not protect human neural progenitor cells and cerebral organoids from Zika virus infection. Cell Stem Cell. 2016;19(6):703-8. doi:10.1016/j.stem.2016.11. 011.

50. El Costa H, Gouilly J, Mansuy JM, Chen Q, Levy C, Cartron G, et al. ZIKA virus reveals broad tissue and cell tropism during the first trimester of pregnancy. Sci Rep. 2016;6:35296. doi:10.1038/ srep35296.

51. Weisblum Y, Oiknine-Djian E, Vorontsov OM, Haimov-Kochman R, Zakay-Rones Z, Meir K, et al. Zika virus infects early- and midgestation human maternal-decidual tissues, inducing distinct innate tissue responses in the maternal-fetal interface. J Virol. 2016; doi:10.1128/jvi.01905-16.

52. Morrison TE, Diamond MS. Animal models of Zika virus infection, pathogenesis, and immunity. J Virol. 2017; doi:10.1128/jvi. 00009-17.

53. Govero J, Esakky P, Scheaffer SM, Fernandez E, Drury A, Platt DJ, et al. Zika virus infection damages the testes in mice. Nature. 2016;540(7633):438-42. doi:10.1038/nature20556.

54. Duggal NK, Ritter JM, Pestorius SE, Zaki SR, Davis BS, Chang GJ, et al. Frequent Zika virus sexual transmission and prolonged viral RNA shedding in an Immunodeficient mouse model. Cell Rep. 2017;18(7):1751-60. doi:10.1016/j.celrep.2017.01.056.

55. Yockey LJ, Varela L, Rakib T, Khoury-Hanold W, Fink SL, Stutz $\mathrm{B}$, et al. Vaginal exposure to Zika virus during pregnancy leads to fetal brain infection. Cell. 2016;166(5):1247-56.e4. doi:10.1016/ j.cell.2016.08.004.

56. Chan JF, Zhang AJ, Chan CC, Yip CC, Mak WW, Zhu H, et al. Zika virus infection in dexamethasone-immunosuppressed mice demonstrating disseminated infection with multi-organ involvement including Orchitis effectively treated by recombinant type I interferons. EBioMedicine. 2016;14:112-22. doi:10.1016/j. ebiom.2016.11.017.

57. Ma W, Li S, Ma S, Jia L, Zhang F, Zhang Y, et al. Zika virus causes testis damage and leads to male infertility in mice. Cell. 2016;167(6):1511-24.e10. doi:10.1016/j.cell.2016.11.016.

58. Vermillion MS, Lei J, Shabi Y, Baxter VK, Crilly NP, McLane M, et al. Intrauterine Zika virus infection of pregnant immunocompetent mice models transplacental transmission and adverse perinatal outcomes. Nat Commun. 2017;8:14575. doi:10.1038/ncomms14575.

59. Tang WW, Young MP, Mamidi A, Regla-Nava JA, Kim K, Shresta S. A mouse model of Zika virus sexual transmission and vaginal viral replication. Cell Rep. 2016;17(12):3091-8. doi:10. 1016/j.celrep.2016.11.070.

60. Osuna CE, Lim SY, Deleage C, Griffin BD, Stein D, Schroeder LT, et al. Zika viral dynamics and shedding in rhesus and cynomolgus macaques. Nat Med. 2016;22(12):1448-55. doi:10.1038/ nm.4206.

61. Koide F, Goebel S, Snyder B, Walters KB, Gast A, Hagelin K, et al. Development of a Zika virus infection model in Cynomolgus macaques. Front Microbiol. 2016;7:2028. doi:10.3389/fmicb. 2016.02028.

62. Haddow AD, Nalca A, Rossi FD, Miller LJ, Wiley MR, PerezSautu U, et al. High infection rates for adult macaques after intravaginal or Intrarectal inoculation with Zika virus. Emerg Infect Dis. 2017;23(8) doi:10.3201/eid2308.170036.
63. Nguyen SM, Antony KM, Dudley DM, Kohn S, Simmons HA, Wolfe B, et al. Highly efficient maternal-fetal Zika virus transmission in pregnant rhesus macaques. PLoS Pathog. 2017;13(5): e1006378. doi:10.1371/journal.ppat.1006378.

64. Sapparapu G, Fernandez E, Kose N, Bin C, Fox JM, Bombardi $\mathrm{RG}$, et al. Neutralizing human antibodies prevent Zika virus replication and fetal disease in mice. Nature. 2016;540(7633):443-7. doi:10.1038/nature20564.

65. Dowd KA, Ko SY, Morabito KM, Yang ES, Pelc RS, DeMaso CR, et al. Rapid development of a DNA vaccine for Zika virus. Science (New York, NY). 2016;354(6309):237-40. doi:10.1126/ science.aai9137.

66. Griffin BD, Muthumani K, Warner BM, Majer A, Hagan M, Audet $\mathrm{J}$, et al. DNA vaccination protects mice against Zika virus-induced damage to the testes. Nat Commun. 2017;8: 15743. doi:10.1038/ncomms 15743.

67. Shan C, Muruato AE, Nunes BT, Luo H, Xie X, Medeiros DB, et al. A live-attenuated Zika virus vaccine candidate induces sterilizing immunity in mouse models. Nat Med. 2017; doi:10.1038/ nm. 4322 .

68. Pardi N, Hogan MJ, Pelc RS, Muramatsu H, Andersen H, DeMaso $\mathrm{CR}$, et al. Zika virus protection by a single low-dose nucleosidemodified mRNA vaccination. Nature. 2017; doi:10.1038/ nature21428.

69. Richner JM, Himansu S, Dowd KA, Butler SL, Salazar V, Fox $\mathrm{JM}$, et al. Modified mRNA vaccines protect against Zika virus infection. Cell. 2017;168(6):1114-25.e10. doi:10.1016/j.cell. 2017.02.017.

70. Xie X, Yang Y, Muruato AE, Zou J, Shan C, Nunes BT, et al. Understanding Zika virus stability and developing a chimeric vaccine through functional analysis. MBio. 2017;8(1) doi:10.1128/ mBio.02134-16.

71. Abbink P, Larocca RA, De La Barrera RA, Bricault CA, Moseley ET, Boyd M, et al. Protective efficacy of multiple vaccine platforms against Zika virus challenge in rhesus monkeys. Science (New York, NY). 2016;353(6304):1129-32. doi:10.1126/ science.aah6157.

72. Dejnirattisai W, Supasa P, Wongwiwat W, Rouvinski A, BarbaSpaeth G, Duangchinda T, et al. Dengue virus sero-crossreactivity drives antibody-dependent enhancement of infection with zika virus. Nat Immunol. 2016;17(9):1102-8. doi:10.1038/ ni.3515.

73. Bardina SV, Bunduc P, Tripathi S, Duehr J, Frere JJ, Brown JA, et al. Enhancement of Zika virus pathogenesis by preexisting antiflavivirus immunity. Science (New York, NY). 2017; doi:10. 1126/science.aal4365.

74. Hamer DH, Wilson ME, Jean J, Chen LH. Epidemiology, prevention, and potential future treatments of sexually transmitted Zika virus infection. Curr Infect Dis Rep. 2017;19(4):16. doi:10.1007/ s11908-017-0571-z.

75. Saiz JC, Martin-Acebes MA. Zika virus: a race in search for antivirals. Antimicrob Agents Chemother. 2017; doi:10.1128/aac. 00411-17.

76. Centers for Disease Control and Prevention. Trioplex real-time RT-PCR assay instructions for use, 2017. https://www.cdc.gov/ zika/pdfs/trioplex-real-time-rt-pcr-assay-instructions-for-use.pdf. Accessed 28 Apr 2017.

77. U.S. Food and Drug Administration. Zika virus Emergency Use Authorization, 2016. https://www.fda.gov/MedicalDevices/ Safety/EmergencySituations/ucm161496.htm\#zika. Accessed 21 Apr 2017.

78. Rabe IB, Staples JE, Villanueva J, Hummel KB, Johnson JA, Rose $\mathrm{L}$, et al. Interim guidance for interpretation of Zika virus antibody test results. MMWR Morb Mortal Wkly Rep. 2016;65(21):543-6. doi:10.15585/mmwr.mm6521e1. 
79. Oduyebo T, Igbinosa I, Petersen EE, Polen KN, Pillai SK, Ailes $\mathrm{EC}$, et al. Update: interim guidance for health care providers caring for pregnant women with possible Zika virus exposure United States, July 2016. MMWR Morb Mortal Wkly Rep. 2016;65(29):739-44. doi:10.15585/mmwr.mm6529e1.

80. Centers for Disease Control and Prevention. Updated laboratory guidance: frequently asked questions, 2016. https://www.cdc.gov/ zika/laboratories/lab-guidance-faq.html. Accessed 21 Apr 2017.

81. Chua A, Prat I, Nuebling CM, Wood D, Moussy F. Update on Zika diagnostic tests and WHO's related activities. PLoS Negl Trop Dis. 2017;11(2):e0005269. doi:10.1371/journal.pntd.0005269.

82. Suy A, Sulleiro E, Rodo C, Vazquez E, Bocanegra C, Molina I, et al. Prolonged Zika virus viremia during pregnancy. N Engl J Med. 2016; doi:10.1056/NEJMc1607580.

83. Announcement: Guidance for U.S. laboratory testing for zika virus infection: implications for health care providers. American Journal of Transplantation: Official Journal of the American Society of Transplantation and the American Society of Transplant Surgeons. 2017;17(2):572. doi:10.1111/ajt.14179

84. Panchaud A, Vouga M, Musso D, Baud D. An international registry for women exposed to Zika virus during pregnancy: time for answers. Lancet Infect Dis. 2016;16(9):995-6. doi:10.1016/ s1473-3099(16)30255-9.

85. Russell K, Oliver SE, Lewis L, Barfield WD, Cragan J, MeaneyDelman D, et al. Update: interim guidance for the evaluation and management of Infants with possible congenital Zika virus infection-United States, August 2016. MMWR Morb Mortal Wkly Rep. 2016;65(33):870-8. doi:10.15585/mmwr.mm6533e2.

86. World Health Organization. Prevention of sexual transmission of Zika virus, 2016. http://www.who.int/csr/resources/publications/ zika/sexual-transmission-prevention/en/. Accessed 21 Apr 2017.

87. Petersen EE, Meaney-Delman D, Neblett-Fanfair R, Havers F, Oduyebo T, Hills SL, et al. Update: Interim guidance for preconception counseling and prevention of sexual transmission of Zika virus for persons with possible Zika virus exposure-United States, September 2016. MMWR Morb Mortal Wkly Rep. 2016;65(39):1077-81. doi:10.15585/mmwr.mm6539e1.

88. American Society for Reproductive Medicine. Guidance for providers caring for women and men of reproductive age with possible zika virus exposure, 2016. http://www.asrm.org/globalassets/ asrm/asrm-content/news-and-publications/practice-guidelines/fornon-members/asrm_zikaguidance_09-13-16.pdf. Accessed 21 Apr 2017.

89. Zafer M, Horvath $\mathrm{H}$, Mmeje O, van der Poel S, Semprini AE, Rutherford G, et al. Effectiveness of semen washing to prevent human immunodeficiency virus (HIV) transmission and assist pregnancy in HIV-discordant couples: a systematic review and meta-analysis. Fertil Steril. 2016;105(3):645-55.e2. doi:10.1016/ j.fertnstert.2015.11.028.

90. Mansuy JM, Suberbielle E, Chapuy-Regaud S, Mengelle C, Bujan L, Marchou B, et al. Zika virus in semen and spermatozoa. Lancet Infect Dis. 2016;16(10):1106-7. doi:10.1016/s1473-3099(16) 30336-x.

91. Agencia Nacional de Vigilancia Sanitaria. Board of Directors Resolution RDC No. 72, March 30, 2016 (in Portuguese). 2016. http://portal.anvisa.gov.br/documents/33880/2568070/RDC_72 2016.\%20pdf/14b66550-3af2-4761-a439-2140c33043cd. Accessed 21 Apr 2017.

92. Carvalho BR, Taitson PF, Brandao KS, Ferriani RA, Nakagawa $\mathrm{HM}$, Silva AA, et al. Reproductive planning in times of Zika: getting pregnant or delaying plans? The opinion of the Brazilian Society of Assisted Reproduction Committee - a basis for a bioethical discussion. JBRA assisted reproduction. 2016;20(3):15964. doi:10.5935/1518-0557.20160034.

93. Agence de la Biomedicine. Professional recommendations for assisted reproduction providers in France and French
Departments of America in context of declining Zika virus circulation (in French). 2017. https://www.agence-biomedecine.fr/ IMG/pdf/2017-002recoampzikav4_26-01-2017-2.pdf. Accessed 21 Apr 2017.

94. U.S. Food and Drug Administration Donor screening recommendations to reduce the risk of transmission of Zika virus by human cells, tissues, and cellular and tissue-based products. 2016. https:// www.fda.gov/downloads/BiologicsBloodVaccines/ GuidanceComplianceRegulatoryInformation/Guidances/Tissue/ UCM488582.pdf. Accessed 21 Apr 2017.

95. Centers for Disease Control and Prevention. CDC identifies potential risk of Zika virus transmission since June 15, 2016, in Miami-Dade, Broward, and Palm Beach counties. 2017. https:// www.cdc.gov/media/releases/2017/s0313-risk-of-zikatransmission-florida.html. Accessed 21 Apr 2017.

96. Souza MD, Raupp V, Sobrinho F, Menezes M, Panaino TR, Tamm MA, et al. Zika virus and assisted reproductive technology: to test or not to test, that is the question. Is it an unnecessary cost? The first two months of mandatory testing in an outbreak area in Rio de Janeiro, Brazil. JBRA Assisted Reproduction. 2016;20(4):195-9. doi:10.5935/1518-0557.20160038.

97. Benjamin I, Fernandez G, Figueira JV, Parpacen L, Urbina MT, Medina R. Zika virus detected in amniotic fluid and umbilical cord blood in an in vitro fertilization-conceived pregnancy in Venezuela. Fertil Steril. 2017; doi:10.1016/j.fertnstert.2017.02. 112.

98. Leal WS, Barbosa RM, Zeng F, Faierstein GB, Tan K, Paiva MH, et al. Does Zika virus infection affect mosquito response to repellents? Sci Rep. 2017;7:42826. doi:10.1038/srep42826.

99. Centers for Disease Control and Prevention. Zika virus: print resources. 2017. https://www.cdc.gov/zika/fs-posters/index.html. Accessed 21 Apr 2017.

100. Lehnert JD, Ellingson MK, Goryoka GW, Kasturi R, Maier E, Chamberlain AT. Use of obstetric practice web sites to distribute Zika virus information to pregnant women during a Zika virus outbreak. Journal of Public Health Management and Practice: JPHMP. 2017; doi:10.1097/ph.0000000000000537.

101. MotherToBaby. Zika Virus and Pregnancy. 2017. https:// mothertobaby.org/fact-sheets/zika-virus-pregnancy/. Accessed 21 Apr 2017.

102. American College of Pediatricians. New concerns about the human papillomavirus vaccine. 2016. https://www.acpeds.org/thecollege-speaks/position-statements/health-issues/new-concernsabout-the-human-papillomavirus-vaccine. Accessed 21 Apr 2017.

103. American Academy of Pediatrics. Vaccine safety: examine the evidence. 2013. https://www.aap.org/en-us/Documents/ immunization vaccine studies.pdf. Accessed 21 Apr 2017.

104. Painter JE, Plaster AN, Tjersland DH, Jacobsen KH. Zika virus knowledge, attitudes, and vaccine interest among university students. Vaccine. 2017; doi:10.1016/j.vaccine.2016.12.050.

105. Washington CI, Haque S, Segars JH, Bracero N, Rodriguez F, Ball GD, et al. Keeping the Zika virus out of the assisted reproductive technology laboratory. Semin Reprod Med. 2016;34(5):293-8. doi:10.1055/s-0036-1592067.

106. Byron K, Howard D. Hey everybody, don't get pregnant: Zika, WHO and an ethical framework for advising. J Med Ethics. 2016. doi:10.1136/medethics-2016-103862.

107. Ahrens KA, Hutcheon JA, Gavin L, Moskosky S. Reducing unintended pregnancies as a strategy to avert Zika-related microcephaly births in the United States: a simulation study. Matern Child Health J. 2017; doi:10.1007/s10995-017-2275-2.

108. Li R, Simmons KB, Bertolli J, Rivera-Garcia B, Cox S, Romero L, et al. Cost-effectiveness of increasing access to contraception during the Zika virus outbreak, Puerto Rico, 2016. Emerg Infect Dis. 2017;23(1):74-82. doi:10.3201/eid2301.161322. 
109. Diniz D, Medeiros M, Madeiro A. Brazilian women avoiding pregnancy during Zika epidemic. The Journal of Family Planning and Reproductive Health Care. 2017;43(1):80. doi:10. 1136/jfprhc-2016-101678.

110. Bahamondes L, Ali M, Monteiro I, Fernandes A. Contraceptive sales in the setting of the Zika virus epidemic. Human Reproduction (Oxford, England). 2017;32(1):88-93. doi:10. 1093/humrep/dew310.

111. Goldthwaite LM, Velasquez G. Family planning and the Zika era. Current Opinion in Obstetrics \& Gynecology. 2016;28(6):499 503. doi:10.1097/gco.0000000000000323.

112. Centers for Disease Control and Prevention. CDC US Zika pregnancy registry healthcare provider toolkit for health departments - for obstetricians. 2017. https://www.cdc.gov/zika/pdfs/ uszpr_toolkit_ob.pdf. Accessed 24 Apr 2017.

113. Centers for Disease Control and Prevention. Zika widgets. 2016. https://www.cdc.gov/widgets/zika/index.html. Accessed 24 Apr 2017.

114. American Congress of Obstetricians and Gynecologists. Zika toolkit. 2016. http://www.acog.org/zikatoolkit. Accessed 24 Apr 2017.

115. Centers for Disease Control and Prevention. World map of areas with risk of Zika. 2017. https://wwwnc.cdc.gov/travel/page/worldmap-areas-with-zika. Accessed 24 Apr 2017.

116. Centers for Disease Control and Prevention. Maps of Zika in the United States. 2017. https://www.cdc.gov/zika/intheus/maps-zikaus.html. Accessed 24 Apr 2017.

117. Pan American Health Organization. Countries and territories of the Americas with confirmed autochthonous cases of Zika virus (vector-borne transmission), 2015-2017 2017. http://ais.paho.org/ phip/viz/ed_zika_countrymap.asp. Accessed 24 Apr 2017.

118. HealthLandscape. Zika mapping tool. 2017. http://www. healthlandscape.org/aafp/zikamapper/map_zika.cfm. Accessed 24 Apr 2017.

119. HealthMap.org. 2016 Zika Outbreak. 2017. http://www. healthmap.org/zika/\#timeline. Accessed 24 Apr 2017.

120. World Health Organization. Zika virus country classification scheme. 2017. http://www.who.int/csr/resources/publications/ zika/classification/en/ Accessed 24 Apr 2017.
121. Gornet ME, Bracero NJ, Segars JH. Zika virus in semen: what we know and what we need to know. Semin Reprod Med. 2016;34(5): 285-92. doi:10.1055/s-0036-1592312.

122. Baud D, Musso D, Vouga M, Alves MP, Vulliemoz N. Zika virus: a new threat to human reproduction. American Journal of Reproductive Immunology (New York, NY : 1989). 2016; doi: 10.1111/aji.12614.

123. Richardson E. Zika travel policies may reduce women's leadership in Global Health. Global Health, Science and Practice. 2016;4(4): 696-7. doi:10.9745/ghsp-d-16-00282.

124. Centers for Disease Control and Prevention. Case Counts in the US. 2017. https://www.cdc.gov/zika/reporting/case-counts.html. Accessed 12 Jun 2017.

125. Grubaugh ND, Ladner JT, Kraemer MUG, Dudas G, Tan AL, Gangavarapu K, et al. Genomic epidemiology reveals multiple introductions of Zika virus into the United States. Nature. 2017; doi:10.1038/nature22400.

126. Bradt DL, Bradley KK, Hoback WW, Noden BH. New Records of Aedes aegypti in Southern Oklahoma, 2016. J Am Mosq Control Assoc. 2017;33(1):56-9. doi:10.2987/16-6627.1.

127. Liu Z, Zhou T, Lai Z, Zhang Z, Jia Z, Zhou G, et al. Competence of Aedes aegypti, Ae. Albopictus, and Culex quinquefasciatus mosquitoes as Zika virus vectors, China. Emerg Infect Dis. 2017;23(7) doi:10.3201/eid2307.161528.

128. Cousins S. Three Zika cases are found in India after random tests. BMJ (Clinical Research ed). 2017;357:j2654. doi:10.1136/bmj. j2654.

129. Singh T. Zika virus: can India win the fight? Indian Journal of Community Medicine: Official Publication of Indian Association of Preventive \& Social Medicine. 2017;42(2):69-72. doi:10.4103/ 0970-0218.205221.

130. Oussayef NL, Pillai SK, Honein MA, Ben Beard C, Bell B, Boyle CA, et al. Zika virus -10 public health achievements in 2016 and future priorities. MMWR Morb Mortal Wkly Rep. 2017;65(52): 1482-8. doi:10.15585/mmwr.mm6552e1.

131. Greer SL, Singer PM. Addressing Zika in the United States: polarization, fragmentation, and public health. Am J Public Health. 2017;107(6):861-2. doi:10.2105/ajph.2017.303772. 